\title{
LITHUANIAN FAMILY FARM ECONOMIC SUSTAINABILITY: DOES THE INDICATOR MATTER?
}

\author{
Vida Dabkienè \\ Lithuanian Institute of Agrarian Economics, Lithuania \\ vida@laei.lt
}

\begin{abstract}
The economic situation of Lithuanian agricultural sector faces with challenges in regards to family farms' income instability and income discrepancies between family farms. The aim of this paper is to assess the economic sustainability of Lithuanian sector at farm level across farm size classes in terms of physical size and by specialization. Furthermore, as the sustainability construction index method was employed as basis to conduct the research, the methodology aspects related to the number of indicators included in the set of indicators and the estimation of thresholds of sustainability intervals were empirically analysed. The findings of economic sub-index assessment indicates very good level of Lithuanian family farms as $68 \%$ of the sample farms were defined by medium level of economic sustainability. The assessment of family farms' economic sustainability by specialization revealed that the horticulture farms performed the highest economic sustainability and, at the other end of spectrum, the COP farms achieved the lowest economic sustainability. As regards the physical size of farms, the best economic sustainability was observed on the smallest farms in terms of size and on the largest farms, of less than 5 ha and from 500 ha or over, respectively.
\end{abstract}

Key words: economic sub-index, indicators, family farms, FADN, farming type.

\section{Introduction}

The beginning in designing indicators of sustainability has come from the United Nations initiative, which launched the program of work on sustainable development indicators for the Commission on Sustainable Development after the Rio Earth Summit in 1992 (Dahl, 2012). Since then different methodologies, frameworks, indicators were developed and presented to assess sustainable development, and still, there is no generally accepted tool (Singh et al., 2012). In the context of achieving sustainable development goals in the whole economy, agricultural sector plays an important role in terms of land management, rural areas development, food security, climate change, biodiversity and etc. A number of scientific research perform overview and systematization of scientific literature focusing on the sustainability assessment methodology aspects (Binder et al., 2010; Singh et al., 2012; Marchand et. al., 2014; Schader et al., 2014; De Olde et al., 2016). The analysis of agricultural sustainability at a farm level is suggested to be the most appropriate spatial unit in terms of the implementation of sustainable farm practices (Kelly et al., 2018). The sustainability analysis usually comprises of economic, environmental and social dimensions of sustainability. Therefore, recently the economic, environmental and social aspects of farms sustainability have been incorporated into farms' sustainability analysis (Zahm et al., 2008; Dantsis et al., 2010; Gomez-Limon \& Sanchez-Fernandez, 2010; Jane Dillon et al., 2016; Lynch et al., 2016; Poppe et al., 2016; Herrera, GersterBentaya, \& Knierim, 2016; Brennan et al., 2016). Recently, European Union (EU) Farm Accountancy Data Network (FADN) has been employed by researchers for farm sustainability analyses across
EU countries (Zahm et al., 2008; Barnes \& Thomson, 2014; O'Donoghue et al., 2016). However, the devised indictors differ and thus limit the comparison of results derived by different researchers.

The economic dimension of agricultural sustainability has become the subject of extensive research since 2010 (Baležentis, Namiotko, \& Novickytè, 2018). Some attempts to assess Lithuanian farms economic sustainability revealed the problematic areas that should be considered in future aiming to increase sustainability level of agricultural sector (Dabkienè, 2018; Baležentis, Namiotko, \& Novickytė, 2018; Vitunskienė \& Dabkienė, 2016). Vitunskienè \& Dabkienè (2016) conducted the analysis of Lithuanian family farms sustainability using farm relative sustainability index, which reflected all three dimensions of sustainable development, in 2003 and 2012. The results revealed that the economic sustainability of farms was low in both considered years. Two challenging areas that relate to farm risk management were identified. Lithuanian family farms showed inability to employ farm's capital (internal capacity) reducing the agricultural business risk and cope with income instability. As well the insurance policy was not suitable and favourable instrument for farmers as the way of stabilizing their income in case of losses due to unanticipated external events. Dabkiene (2018) presented the analysis of farms economic sustainability in 2014 with regard to farms' specialization. The findings highlight the need of monitoring farms' economic situation as the economic sustainability index value was estimated lower in 2014 than in 2012. The author organized experts' questionnaire in order to assign the weights to the developed indicators for family farm sustainability assessment. In the questionnaire, it was asked whether 
there were any other indicators which should be taken into account. The experts suggested including the indicator addressed to farm's autonomy considering the importance of this criteria on farms' economic sustainability (detailed results of questionnaire presented in Dabkienė, 2018). Baležentis, Namiotko \& Novickyte (2018) conducted the analysis of Lithuanian family farms economic sustainability in terms of farm investments, profitability and growth. The results disclosed economic sustainability problem areas of Lithuanian farms. The authors emphasize that the estimated low level of profitability and growth for the specialist granivores, grazing livestock, specialist dairying and field crops-grazing livestock combined farms may negatively affect their economic sustainability.

The current economic situation of Lithuanian agricultural sector faces with challenges achieving its sustainability (Lithuanian institute of agrarian economics, 2016). According to Eurostat data, Lithuanian agricultural factor income per annual work unit in 2018 stood at EUR 4.4 thou and was by $30 \%$ lower than in 2017 . It could be stated that in 2018 the agricultural labour productivity was low as it only came to around $26 \%$ of the EU-28 level. In 2018, the entrepreneurial income, expressed as entrepreneurial income at real prices per family work unit, in Lithuania amounted to EUR 2.4 thou and it made $17 \%$ of the EU-28 level. The economic situation of Lithuanian family farms' is not even in terms of farm size. According to the EU FADN data, during the period of 2012-2016, regarding farms' economic size, the average value of Lithuanian family farm net income (FNI) per family work unit was the highest on farms with more than 500 Economic Size Units (ESU), whereas the lowest income was registered on farms from 2 to 8 ESU (EUR 2.7 thou and EUR 236.7 thou, respectively). The highest Lithuanian family FNI per family work unit, in terms of physical size (ha of utilized agricultural area (UAA)), over the period of 2013-2017, was registered on farms of 150 ha UAA or over and it was six-fold higher as compared with average income in farms. In 2017, Lithuanian family FNI per family worker, as compared to the average net earnings in the whole Lithuanian economy, was greater by $30 \%$. However, the FNI per family work unit was not sufficient on farms in size classes up to 40 ha UAA, as income was lower than average earnings in the whole economy. It should be noted that small farms are predominant in Lithuania. According to Results of the Farm Structure Survey 2016, farms up to 40 ha UAA came to around $90 \%$ of all farms.

The need for family farms' economic sustainability monitoring and the results of aforementioned questionnaire survey inspired the aim of this paper, which is twofold: (1) to assess economic farm sustainability across farm size classes in terms of physical size and by farms specialization in Lithuania and (2) to evaluate the contribution of additional indicator, namely farm's income reliance on subsidies, to farms' economic sustainability sub-index value.

\section{Materials and Methods}

The sustainability construction index method was employed as the basis to conduct the research. The set of indicators with regard to family farms' economic sustainability assessment developed by Vitunskiene \& Dabkienè (2016) were utilized. Based on proposed methodology by European Commission (2018), the family farms' income reliance on subsidies was measured as the ratio of total subsidies excluding on investments over the farm net value added. Lithuanian FADN 2016 primary data of 1301 family farms concerning economic activity were utilized. Table 1 shows the indicators and their data source to assess family farm economic sustainability.

All the indicators were normalized based on minimum and maximum value. The indicators accepted the values ranging from 0 (indicating low sustainability) to 1 (indicating high sustainability). The maximum values of indicators $\mathrm{e}_{1}-\mathrm{e}_{8}$ and the minimum value of indicator $\mathrm{e}_{9}$ were considered as positive values in terms of economic sustainability. In order to solve problems of outlies, $5^{\text {th }}$ and $95^{\text {th }}$ percentile was used as a minimum and maximum value, respectively. Two economic farms sustainability sub-indices were computed for the evaluation of the impact of the added indicator for the assessment of farms' economic sustainability. The first sub-index consisted of equally weighted 8 indicators (notated as $\mathrm{I}_{\text {sub } 8}$ ) and the second comprised of 9 indicators (notated as $\mathrm{I}_{\text {sub } 9}$ ), thus the weights of the indicators equalled to 0.25 and 0.11 , respectively. In the latter economic sub-index the variable indicating farms reliance on subsidies has been taken into account.

Based on the approach proposed by Savickiene \& Miceikiene (2018) the thresholds values of farms' economic sustainability intervals were estimated. Based on descriptive statistics the upper threshold value of weak sustainability interval was calculated as follows:

$$
B w=\bar{X}-S D,
$$

where by $B w$ - upper threshold value of week sustainability interval; $\bar{X}$ - mean of sub-index; and is standard deviation of sub-index.

The upper threshold of medium sustainability interval value was calculated according to the equation:

$$
B m=2 S D+(\bar{X}-S D),
$$

where by $B m$ is an upper threshold value of medium sustainability level. 
Economic sustainability indicators of the family farm

\begin{tabular}{|c|l|c|c|}
\hline Notation & \multicolumn{1}{|c|}{ Variable } & Indicator & Data source: FADN variables \\
\hline $\mathrm{e}_{1}$ & Labour productivity & $\begin{array}{c}\text { Gross value added } \\
\text { Annual work unit (AWU) }\end{array}$ & SE410; SE425 \\
\hline $\mathrm{e}_{2}$ & Capital productivity & $\frac{\text { Gross value added }}{\text { Total assets }}$ & SE410; SE436 \\
\hline $\mathrm{e}_{3}$ & Land productivity & Hectare (ha) of utilized agricultural area (UAA) & SE410; SE025 \\
\hline $\mathrm{e}_{4}$ & Solvency & $\frac{\text { Total assets }}{\text { Total liabilities }}$ & SE436; SE485 \\
\hline $\mathrm{e}_{5}$ & Farm income & $\frac{\text { Family Farm income }}{\text { Family work unit }}$ & SE430 \\
\hline $\mathrm{e}_{6}$ & Fixed capital formation & $\frac{\text { Gross investment }}{\text { Hectare of UAA }}$ & SE516; SE025 \\
\hline $\mathrm{e}_{7}$ & Farm diversification & $\frac{\text { Revenue from other gainful activities (OGA) }}{\text { Total farm revenue }}$ & $\begin{array}{c}\text { Table 22 in Lithuanian FADN } \\
2016\end{array}$ \\
\hline $\mathrm{e}_{8}$ & Farm risk management & $\begin{array}{c}\text { Insurance costs } \\
\text { Total specific costs }\end{array}$ & $\begin{array}{c}\text { Table 12 in Lithuanian FADN } \\
\text { 2016, SE 281 }\end{array}$ \\
\hline $\mathrm{e}_{9}$ & $\begin{array}{l}\text { Income reliance on } \\
\text { subsidies }\end{array}$ & $\frac{\text { Total subsidies excluding on investments }}{\text { Farm net value added }}$ & SE605; SE415 \\
\hline
\end{tabular}

Table 2

Economic sustainability intervals and farms' sample distribution according to sustainability level

\begin{tabular}{|c|c|c|c|c|c|c|c|}
\hline \multirow{2}{*}{$\begin{array}{c}\text { Economic } \\
\text { sub-index }\end{array}$} & \multicolumn{3}{|c|}{ Descriptive statistics } & \multicolumn{2}{c|}{ Sustainability intervals/sustainability level } \\
\cline { 2 - 8 } & Minimum & Maximum & Mean & SD & $\begin{array}{c}\text { Low } \\
\text { (number of farms) }\end{array}$ & $\begin{array}{c}\text { Medium } \\
\text { (number of farms) }\end{array}$ & $\begin{array}{c}\text { High } \\
\text { (number of farms) }\end{array}$ \\
\hline$I_{\text {sub8 }}$ & 0.07 & 0.67 & 0.31 & 0.11 & $\begin{array}{c}\leq 0.20 \\
(211)\end{array}$ & $\begin{array}{c}0.201-\leq 0.42 \\
(879)\end{array}$ & $\begin{array}{c}0.421-\leq 1 \\
(211)\end{array}$ \\
\hline$I_{\text {sub9 }}$ & 0.06 & 0.65 & 0.32 & 0.11 & $\begin{array}{c}\leq 0.22 \\
(211)\end{array}$ & $\begin{array}{c}0.221-\leq 0.43 \\
(877)\end{array}$ & $\begin{array}{c}0.431-\leq 1 \\
(210)\end{array}$ \\
\hline
\end{tabular}

Farms sample distribution regarding to farms' sustainability levels are presented in Table 2.

The statistical analysis was conducted by SPSS 21. Kolmogorov-Smirnov and Shapiro-Wilk tests were used to verify the normality assumption of normalized values. The results indicated that normalized values did not follow a normal distribution. Therefore, the Kruskal-Wallis one-way analysis of variance was used to compare differences among the economic indicators values and sub-indices values across nine types of farming (specialization) and eleven farm physical size classes. A $p$ value of $p<0.05$ was considered to be statistically significant. In describing the results descriptive statistic such as mean and the coefficient of variance $(\mathrm{CV})$ were used.

\section{Results and Discussion}

Derived indicators attributed to agricultural economic sustainability at a farm level enable disclose problems on the farm or in a certain farm group. The lowest values for the whole farms sample were obtained for indicators related to farm's risk management issues: farmers were not engaged in the diversification of their economic activity and were not employing insurance instruments. These findings are in consisted with that estimated by Vitunskienè \& Dabkiene (2016) and disclose long-term problem issues for Lithuanian farms.

The carried out analysis of economic indicators across farm specialization showed that the highest level of labour productivity was achieved on specialist cereals, oilseeds and protein crop (COP) farms and followed by specialist granivore (poultry, pigs) farms, whereas the lowest values were determined on horticulture farms. The highest capital productivity was achieved for specialist granivore farms, though the COP farms recorded the lowest capital productivity. The horticulture farms obtained the highest level of land productivity, whereas, the lowest result was achieved on the COP farms. The land productivity differs across farm specializations as the productivity gap between highest and lowest 


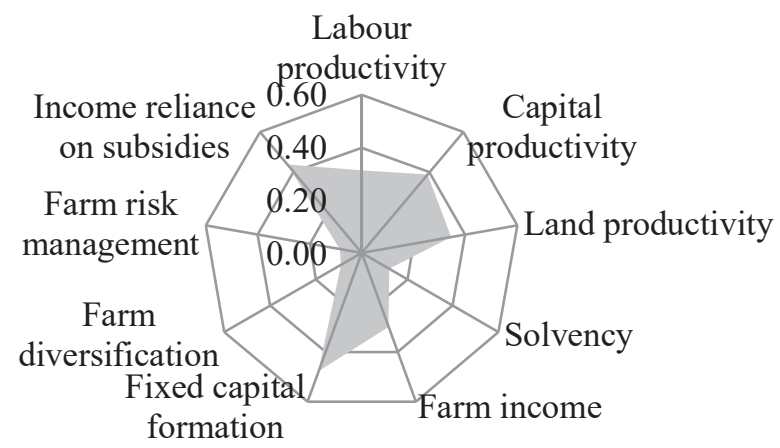

Figure 1. Sub-index of economic sustainability of Lithuanian family farms in 2016.

record was six-fold. The variation of solvency across farm specialization was apparent (CV 52\%): permanent crop farms were the most solvent followed by grazing livestock farms, whereas, the least solvent were specialist granivore farms. The highest income per FWU was registered on specialist granivore farms followed by grazing livestock farms. The findings for fixed capital formation suggest that the horticulture farms invested most in 2016. Medium variation value of fixed capital formation (12.9\%) was defined showing that in terms of investment farms across specializations were similar. Farm income diversification is an important indicator for farm viability, though the normalized values across farm specialization were low showing that small number of sample farms has received income from other gainful activities. Lithuanian farms had paid little attention towards insurance, though the variation of normalized values of the risk management indicator was distinct. The COP farmers were most interested in insurance as the way of stabilizing their income in case of losses due to unanticipated external events. The production support in terms of paid subsidies to farmers might negatively impact their decisions towards specialization or decrease their self-sufficiency level. The greatest reliance on subsidies was observed on farms specialized on grazing livestock. However, the low value of $\mathrm{CV}(9.2 \%)$ indicated marginal differences across farms' specializations (Table 3). Kruskal-Wallis test showed that the performances of economic indicators values notated as $\mathrm{e}_{2}, \mathrm{e}_{3}, \mathrm{e}_{4}, \mathrm{e}_{5}, \mathrm{e}_{6}$ and $e_{9}$ in considered farm groups regarding farms' specialization were significantly different from each other at $\mathrm{p}<0.001$ level, for indicator notated as $\mathrm{e}_{8}$ values were significantly different at $\mathrm{p}<0.01$ level and performances were not significantly different for $\mathrm{e}_{7}$.

\section{Lithuanian family farms economic sustainability indicators by farm specialization in 2016}

Table 3

\begin{tabular}{|c|c|c|c|c|c|c|c|c|c|}
\hline Farm specialization & 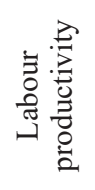 & 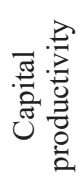 & 疍 & $\begin{array}{l}\text { Dे } \\
\overline{0} \\
\text { Dे } \\
\text { i }\end{array}$ & 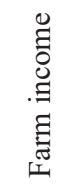 & 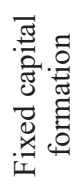 & 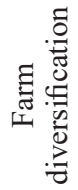 & 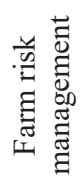 & 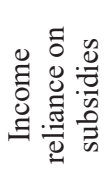 \\
\hline & $\mathrm{e}_{1}$ & $\mathrm{e}_{2}$ & $\mathrm{e}_{3}$ & $\mathrm{e}_{4}$ & $\mathrm{e}_{5}$ & $\mathrm{e}_{6}$ & $\mathrm{e}_{7}$ & $\mathrm{e}_{8}$ & $\mathrm{e}_{9}$ \\
\hline COP & 0.38 & 0.33 & 0.21 & 0.09 & 0.28 & 0.45 & 0.09 & 0.11 & 0.46 \\
\hline General field cropping & 0.32 & 0.34 & 0.36 & 0.10 & 0.31 & 0.52 & 0.11 & 0.04 & 0.47 \\
\hline Horticulture & 0.17 & 0.52 & 0.83 & 0.15 & 0.32 & 0.65 & 0.12 & 0.00 & 0.51 \\
\hline Permanent crops & 0.23 & 0.50 & 0.52 & 0.26 & 0.26 & 0.45 & 0.10 & 0.02 & 0.46 \\
\hline Specialist dairying & 0.28 & 0.46 & 0.45 & 0.12 & 0.31 & 0.46 & 0.09 & 0.10 & 0.42 \\
\hline Grazing livestock & 0.29 & 0.38 & 0.35 & 0.22 & 0.34 & 0.53 & 0.08 & 0.10 & 0.38 \\
\hline Specialist granivores & 0.36 & 0.58 & 0.70 & 0.03 & 0.44 & 0.46 & 0.07 & 0.02 & 0.49 \\
\hline Field crops-grazing livestock, combined & 0.32 & 0.39 & 0.29 & 0.12 & 0.32 & 0.47 & 0.10 & 0.06 & 0.41 \\
\hline Various crops and livestock combined & 0.13 & 0.41 & 0.45 & 0.11 & 0.21 & 0.50 & 0.07 & 0.03 & 0.48 \\
\hline $\mathrm{CV}$ & 30.5 & 19.7 & 42.7 & 52.0 & 20.2 & 12.9 & 18.6 & 76.7 & 9.2 \\
\hline Significance & $* * *$ & $* * *$ & $* * *$ & $* * *$ & $* * *$ & $* * *$ & NS & $* *$ & $* * *$ \\
\hline
\end{tabular}

Level of statistical significance are ${ }^{*} \mathrm{p}<0.05,{ }^{* *} \mathrm{p}<0.01,{ }^{* * *} \mathrm{p}<0.001$ and NS - not significant 
The farm labour productivity increases with the physical size of family farm. The highest level of labour productivity was achieved on farms from 50 ha and over. The variation of labour productivity among farm size classes was evident (CV 76.2\%). The highest level of capital productivity was recorded on the smallest farms size class (of less than $5 \mathrm{ha}$ ). Medium variation of capital productivity values (CV $14.9 \%$ ) indicates rather different situation across farm specializations. On contrary to the labour productivity tendency, the land productivity decreases with the physical size of family farm, though the variation of values across defined farm size classes was lower $(\mathrm{CV}$ $25.1 \%)$. The most solvent farms were determined on farm size class from 5 to 10 ha of UAA. The best farms in regards to their risk-bearing ability were found on farms from 5 to 10 ha of UAA, while the least solvent farms were observed in the largest size class (500 ha or over). Findings on family farm income distribution across defined farm size classes suggest that income depends on farm's physical size. The highest income was generated by farms on the largest farm size class (500 ha or over). The expenditure to the on-farm investment is one of indicators showing farmer's attitude towards farm's long term competiveness and ensuring farm's improvement of efficiency. Looking at normalized fixed capital formation values, the highest value of this indicator was observed on the smallest farm size class (of less than $5 \mathrm{ha}$ ), while the lowest values were determined on farms from 40 to 200 ha of UAA. The results reveal that the investments differed slightly across farm size classes (CV 8.8\%). The most diversifying income from other gainful activities farms were found on farm size class from 5 to 10 ha of UAA. The insurance as a farm risk management tool was more widely used by farms on the largest farm size class (500 ha or over). The variation of farm risk management among farm size classes was apparent (CV 71.4\%). The highest level of farms' income reliance on subsidies was achieved on farm size class from 40 to 50 ha of UAA. At the other end of the spectrum, farms on the smallest farm size class (of less than $5 \mathrm{ha}$ ) were least dependent on subsidies (Table 4).

Kruskal-Wallis test showed that the performances of economic indicators values notated as $\mathrm{e}_{2}, \mathrm{e}_{4}, \mathrm{e}_{5}, \mathrm{e}_{6}, \mathrm{e}_{8}$ and $\mathrm{e}_{9}$ in considered farms' physical size groups were significantly different from each other at $\mathrm{p}<0.001$ level, for indicator notated as $\mathrm{e}_{3}$ values were significantly different at $p<0.01$ level and performances were not significantly different for $\mathrm{e}_{7}$.

Table 5 shows average values of economic subindices derived by farms' specializations and according to physical farm size classes. The derived economic sub-indices $I_{\text {sub } 8}$ and $I_{\text {sub } 9}$ values were almost identical, indicating little impact of farm's income autonomy

\section{Lithuanian family farms economic sustainability indicators by farm size classes}

Table 4

\begin{tabular}{|c|c|c|c|c|c|c|c|c|c|}
\hline Farm size classes of UAA & 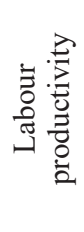 & 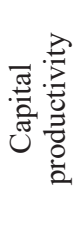 & 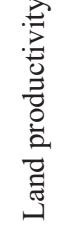 & 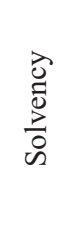 & 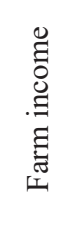 & 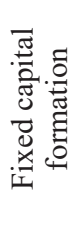 & 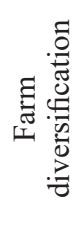 & 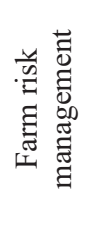 & 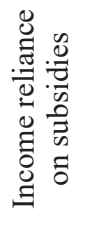 \\
\hline & $\mathrm{e}_{1}$ & $\mathrm{e}_{2}$ & $\mathrm{e}_{3}$ & $\mathrm{e}_{4}$ & $\mathrm{e}_{5}$ & $\mathrm{e}_{6}$ & $\mathrm{e}_{7}$ & $\mathrm{e}_{8}$ & $\mathrm{e}_{9}$ \\
\hline Less than 5 ha & 0.08 & 0.51 & 0.61 & 0.14 & 0.19 & 0.59 & 0.11 & 0.00 & 0.57 \\
\hline From 5 to 10 ha & 0.04 & 0.30 & 0.40 & 0.22 & 0.19 & 0.50 & 0.14 & 0.06 & 0.54 \\
\hline From 10 to 20 ha & 0.08 & 0.36 & 0.42 & 0.17 & 0.20 & 0.51 & 0.09 & 0.03 & 0.44 \\
\hline From 20 to 30 ha & 0.13 & 0.42 & 0.42 & 0.15 & 0.21 & 0.50 & 0.07 & 0.08 & 0.45 \\
\hline From 30 to 40 ha & 0.14 & 0.38 & 0.33 & 0.17 & 0.23 & 0.53 & 0.07 & 0.03 & 0.41 \\
\hline From 40 to 50 ha & 0.17 & 0.40 & 0.30 & 0.17 & 0.23 & 0.45 & 0.10 & 0.06 & 0.40 \\
\hline From 50 to 100 ha & 0.28 & 0.42 & 0.32 & 0.16 & 0.27 & 0.46 & 0.11 & 0.07 & 0.42 \\
\hline From 100 to 150 ha & 0.40 & 0.43 & 0.33 & 0.09 & 0.31 & 0.45 & 0.08 & 0.11 & 0.44 \\
\hline From 150 to 200 ha & 0.47 & 0.39 & 0.32 & 0.06 & 0.32 & 0.45 & 0.07 & 0.11 & 0.45 \\
\hline From 200 to 500 ha & 0.56 & 0.35 & 0.32 & 0.04 & 0.43 & 0.47 & 0.10 & 0.11 & 0.44 \\
\hline 500 ha or over & 0.59 & 0.32 & 0.29 & 0.03 & 0.56 & 0.48 & 0.07 & 0.21 & 0.46 \\
\hline $\mathrm{CV}$ & 76.2 & 14.9 & 25.1 & 49.0 & 40.8 & 8.8 & 24.7 & 71.4 & 11.5 \\
\hline Significance & $* * *$ & $* * *$ & $* *$ & $* * *$ & $* * *$ & $* * *$ & NS & $* * *$ & $* * *$ \\
\hline
\end{tabular}

Level of statistical significance are $* \mathrm{p}<0.05,{ }^{*} \mathrm{p}<0.01, * * * \mathrm{p}<0.001$ and NS - not significant 
Lithuanian farm economic sub-indices values by specialization and family farm size classes

\begin{tabular}{|c|c|c|}
\hline & Economic sub-index $\left(I_{\text {subs }}\right)$ & Economic sub-index $\left(I_{\text {sub }}\right)$ \\
\hline \multicolumn{3}{|l|}{ Family farm specialization } \\
\hline $\mathrm{COP}$ & 0.29 & 0.30 \\
\hline General field cropping, mixed cropping & 0.32 & 0.33 \\
\hline Horticulture & 0.41 & 0.42 \\
\hline Permanent crops & 0.35 & 0.36 \\
\hline Specialist dairying & 0.32 & 0.33 \\
\hline Grazing livestock & 0.32 & 0.33 \\
\hline Specialist granivores & 0.39 & 0.40 \\
\hline Field crops-grazing livestock, combined & 0.30 & 0.32 \\
\hline Various crops and livestock combined & 0.30 & 0.32 \\
\hline $\mathrm{CV}$ & 12.5 & 11.6 \\
\hline Significance & $* * *$ & $* * *$ \\
\hline \multicolumn{3}{|l|}{ Family farms size classes ha of UAA } \\
\hline Less than 5 ha & 0.35 & 0.37 \\
\hline From 5 to 10 ha & 0.29 & 0.32 \\
\hline From 10 to 20 ha & 0.28 & 0.30 \\
\hline From 20 to 30 ha & 0.29 & 0.31 \\
\hline From 30 to 40 ha & 0.28 & 0.30 \\
\hline From 40 to 50 ha & 0.28 & 0.29 \\
\hline From 50 to 100 ha & 0.31 & 0.32 \\
\hline From 100 to 150 ha & 0.31 & 0.33 \\
\hline From 150to 200 ha or over & 0.32 & 0.33 \\
\hline From 200 to 500 ha & 0.34 & 0.35 \\
\hline 500 ha or over & 0.35 & 0.36 \\
\hline Total & 0.31 & 0.32 \\
\hline $\mathrm{CV}$ & 8.6 & 7.6 \\
\hline Significance & $* * *$ & $* * *$ \\
\hline
\end{tabular}

Level of statistical significance are ${ }^{*} \mathrm{p}<0.05,{ }^{* *} \mathrm{p}<0.01,{ }^{* * *} \mathrm{p}<0.001$ and NS - not significant

criteria to farms' economic sustainability values. Alongside, the developed sub-indices demonstrated almost the same tendencies and there were minor differences across specializations of farms and by physical size classes. The findings of sub-indices assessment indicates very good level of Lithuanian family farms as $68 \%$ of the sample farms were defined by medium level of economic sustainability (Table 2). With regard to the farms' specialization, horticulture farms performed the highest economic sustainability. The COP farms in contrast were the least sustainable from economic perspective. As regards the physical size of farms, the best economic sustainability was observed on the smallest-sized farms and on the largest-sized farms, of less than 5 ha and from 500 ha or over, respectively. There were greater differences in economic sub-indices values across specializations of farms than across physical farm size classes, indicating that the farms' specialization is more significant for economic sustainability than their physical size. Kruskal-Wallis test showed that the performances of economic sub-indices values notated as $I_{\text {sub } 8}$ and $I_{\text {sub } 9}$ in considered farms' specialization and physical size groups were significantly different from each other at $\mathrm{p}<0.001$ level.

\section{Conclusions}

The findings of economic sub-index assessment indicates a very good level of Lithuanian family farms as $68 \%$ of the sample farms were defined by medium level of economic sustainability. The assessment of family farms' economic sustainability by specialization revealed that the horticulture farms performed the highest economic sustainability and, at the other end of spectrum, the COP farms achieved the lowest economic sustainability. As regards the 
physical size of farms, the best economic sustainability was observed on the smallest farms in terms of size and on the largest farms, of less than 5 ha and from 500 ha or over, respectively.

The contribution of additional indicator, namely farm's income reliance on subsidies, to farms' economic sustainability sub-index value was minimal, though the reason for that could be more addressed to the aggregation method used in the research. Therefore, employing the sustainability index as a policy making decisions tool, the assignment of weights to indicators through methods such as the principal components analysis, expert questionnaire or others should be verified.

\section{References}

1. Baležentis, T., Namiotko, V., \& Novickyte, L. (2018). Lithuanian family farm profitability: The economic dimension of sustainability: Scientific Study. Vilnius: Lithuanian Institute of Agrarian Economics. p. 104.

2. Barnes, A.P., \& Thomson, S.G. (2014). Measuring progress towards sustainable intensification: how far can secondary data go? Ecological indicators, 36, 213-220. DOI: 10.1016/j.ecolind.2013.07.001.

3. Binder, C.R., Feola, G., \& Steinberger, J.K. (2010). Considering the normative, systemic and procedural dimensions in indicator-based sustainability assessments in agriculture. Environmental impact assessment review, 30(2), 71-81. DOI: 10.1016/j.eiar.2009.06.002.

4. Brennan, N., Ryan, M., Hennessy, T., Dillon, E.J., \& Cullen, P. (2016). The role of extension in agricultural sustainability. FLINT Deliverable D 5.

5. Dabkienė, V. (2018). Šeimos ūkiu santykinio darnumo vertinimas: metodologija ir taikymas (The relative sustainability of the family farm assessment: methodology and application). Scientific Monograph (in Lithuanian language). Vilnius: Lithuanian Institute of Agrarian Economics. 115 p. (in Lithuanian)

6. Dahl, A.L. (2012). Achievements and gaps in indicators for sustainability. Ecological Indicators, 17, 1419. DOI: 10.1016/j.ecolind.2011.04.032.

7. Dantsis, T., Douma, C., Giourga, C., Loumou, A., \& Polychronaki, E.A. (2010). A methodological approach to assess and compare the sustainability level of agricultural plant production systems. Ecological indicators, 10(2), 256-263. DOI: 10.1016/j.ecolind.2009.05.007.

8. De Olde, E.M., Oudshoorn, F.W., Sørensen, C.A., Bokkers, E.A., \& De Boer, I.J. (2016). Assessing sustainability at farm-level: Lessons learned from a comparison of tools in practice. Ecological Indicators, 66, 391-404. DOI: 10.1016/j.ecolind.2016.01.047.

9. Dillon, J.E., Hennessy, T., Buckley, C., Donnellan, T., Hanrahan, K., Moran, B., \& Ryan, M. (2016). Measuring progress in agricultural sustainability to support policy-making. International Journal of Agricultural Sustainability, 14(1), 31-44. DOI: 10.1080/14735903.2015.1012413.

10. European Commission. (2015). Technical Handbook on the Monitoring and Evaluation Framework of the Common Agricultural Policy 2014-2020. Directorate General for Agriculture and Rural Development, Brussels, Belgium.

11. European Commission. (2018). EU farm economics overview FADN 2015. Brussels.

12. Frater, P., Franks, J. (2013). Measuring agricultural sustainability at the farm-level: A pragmatic approach. International Journal of Agricultural Management, Vol. 2, No. 4, pp. 207-225. DOI: 10.5836/ijam/201304-04.

13. Gómez-Limón, J.A., \& Sanchez-Fernandez, G. (2010). Empirical evaluation of agricultural sustainability using composite indicators. Ecologicaleconomics, 69(5), 1062-1075.DOI: 10.1016/j.ecolecon.2009.11.027.

14. Herrera, B., Gerster-Bentaya, M., \& Knierim, A. (2016). Stakeholders' perceptions of sustainability measurement at farm level. Proceedings 'Schriften der Gesellschaftfür Wirtschafts-und Sozialwissenschaften des Landbaues eV', 51(874-2017-1395), 193.

15. Jane Dillon, E., Hennessy, T., Buckley, C., Donnellan, T., Hanrahan, K., Moran, B., \& Ryan, M. (2016). Measuring progress in agricultural sustainability to support policy-making. International Journal of Agricultural Sustainability, 14(1), 31-44. DOI: http://dx.doi.org/10.1080/14735903.2015.1012413.

16. Kelly, E., Latruffe, L., Desjeux, Y., Ryan, M., Uthes, S., Diazabakana, A., ... Finn, J. (2018). Sustainability indicators for improved assessment of the effects of agricultural policy across the EU: Is FADN the answer? Ecological indicators, 89, 903-911. DOI: 10.1016/j.ecolind.2017.12.053.

17. Lynch, J., Hennessy, T., Buckley, C., Dillon, E., Donnellan, T., Hanrahan, K., ,.. Ryan, M. (2016). Teagasc national farm survey 2015 sustainability report. Athenry, Co. Galway: Teagasc.

18. Marchand, F., Debruyne, L., Triste, L., Gerrard, C., Padel, S., \& Lauwers, L. (2014). Key characteristics for tool choice in indicator-based sustainability assessment at farm level, Ecology and Society, 2014, 19(3): 46. DOI: 10.5751/ES-06876-190346. 
19. O’Donoghue, C., Devisme, S., Ryan, M., Conneely, R., \& Gillespie, P. (2016). Farm economic sustainability in the European Union: A pilot study. Studies in Agricultural Economics, 118(3), $163-171$. DOI: $10.7896 /$ j.1631.

20. Poppe, K., Vrolijk, H., Dolman, M., \& Silvis, H. (2016). FLINT-Farm-level Indicators for New Topics in policy evaluation: an introduction. Studies in Agricultural Economics, 118(3), 116-122. DOI: 10.7896/j.1627.

21. Savickienè, J., \& Miceikienè, A. (2018). Sustainable economic development assessment model for family farms. Agricultural Economics, 64(12), 527-535. DOI: 10.17221/310/2017-AGRICECON.

22. Schader, C., Grenz, J., Meier, M.S., \& Stolze, M. (2014). Scope and precision of sustainability assessment approaches to food systems. Ecology \& Society, 19(3), DOI: 10.5751/ES-06866-190342.

23. Lithuanian institute of agrarian economies (2016). Pasiūlymai dèl Lietuvos žemès ūkio ir kaimo plètros strateginių krypčiu ir siekinių iki 2030 metų 'Tvarus Lietuvos žemès ūkis - gyvybingam kaimui' (Proposals for Strategic Directions and Objectives of Lithuanian Agriculture and Rural Development until 2030 'Lithuanian sustainable agriculture for viable rural areas'). Vilnius. (in Lithuanian)

24. Singh, R.K., Murty, H.R., Gupta, S.K., \& Dikshit, A.K. (2012). An overview of sustainability assessment methodologies. Ecological indicators, 15(1), 281-299. DOI: 10.1016/j.ecolind.2008.05.011.

25. Vitunskiene, V., \& Dabkiene, V. (2016). Framework for assessing the farm relative sustainability: a Lithuanian case study. Agric. Econ.-Czech. 62, 134-148. DOI: 10.17221/125/2015-AGRICECON.

26. Zahm, F., Viaux, P., Vilain, L., Girardin, P., \& Mouchet, C. (2008). Assessing farm sustainability with the IDEA method-from the concept of agriculture sustainability to case studies on farms. Sustainable development, 16(4), 271-281. DOI: 10.1002/sd.380. 